heavy solute load in cow's milk is presented to kidneys with a relative functional immaturity.

Though the changes which occur in serum calcium and magnesium levels in the neonatal period have been studied by others (Gittleman et al., 1964; Harvey et al., 1970), there is little agreement on the precise values which should be accepted as abnormal. A serum calcium level of $7 \mathrm{mg} / 100 \mathrm{ml}$ or below was chosen in this paper, and this is lower than has generally been accepted in the past (Keen, 1969). No attempt has been made to define accurately normal serum magnesium levels. Harvey et al. (1970), using atomic absorption spectrophotometry, showed a mean serum magnesium concentration of 1.4 $\mathrm{mg} / 100 \mathrm{ml}$ in 25 bottle-fed babies on the sixth day of life. However, the range of results was very wide, $0.85-1.9 \mathrm{mg} / 100 \mathrm{ml}$. Suffice to note that the oedematous babies had abnormally low levels for this laboratory, as did several of the non-oedematous babies with the lower serum calcium levels.

The positive correlation between calcium and magnesium levels was apparent only in the babies who were not oedematous. There is conflicting evidence concerning the role of parathyroid hormone in magnesium metabolism (Jones and Fourman, 1966). However, the case of a newborn baby with congenital absence of the parathyroid glands, described by Taitz et al. (1966), supports the view that serum calcium and magnesium levels are influenced in the same way by parathyroid hormone, as this baby had tetany associated with hypocalcaemia and hypomagnesaemia.

The rise in the serum magnesium levels which was seen in the non-oedematous babies when calcium supplements were given has been noted previously in hypocalcaemic babies (Gittleman et al., 1964). It may be that the correction of the hypocalcaemia in these babies allows magnesium to be released from bone and muscle, in keeping with the view that there is a common transport mechanism for calcium and magnesium (Alcock and MacIntyre, 1962).

With regard to the six oedematous babies, the fact that the serum magnesium levels were abnormally low, that there was no correlation between magnesium and calcium levels, and that magnesium levels did not rise on giving calcium supplements, suggests that there was some other factor influencing the magnesium levels. The low magnesium levels cannct be explained by a lowered protein-bound magnesium fraction, as the total protein and albumin levels were similar in the oedematous and non-oedematous babies.

Aldosterone favours renal excretion of magnesium, and increased renal excretion rates of magnesium have been found in primary aldosteronism (Mader and Iseri, 1955), and may also occur in secondary aldosteronism (Kobayashi and Shiraki, 1967). It may be that secondary aldosteronism, induced by the transient fluid retention, influenced the serum magnesium levels in the oedematous babies under study. The low plasma sodium and normal plasma potassium levels are consistent with secondary aldosteronism in association with fluid retention (Johnston, 1969).

Though none of the babies with hypomagnesaemia reported in this paper required magnesium supplements to control the twitching, it is suggested that oedema should be carefully sought in babies with hypocalcaemic tetany, together with a careful appraisal of the weight chart. The presence of oedema and excess weight gain in a baby with tetany not responding to calcium supplements should alert one to the possibility of hypomagnesaemia. Further work may show whether the use of an aldosterone antagonist is more basic to the needs of the oedematous baby with hypocalcaemic tetany.

I am indebted to Dr. J. E. Middleton, consultant in chemical pathology, for his invaluable advice and help. My thanks are also due to all senior house officers in paediatrics employed by Southampton Group Hospital Management Committee who co-operated with me in this study. All the babies were under the care of Dr. D. A. J. Williamson, consultant paediatrician, whom I thank for his encouragement.

\section{References}

Alcock, N., and MacIntyre, I. (1962). Clinical Science, 22, 185.

Anast, C. (1969). Endocrine and Genetic Diseases of Childhood. ed. L. I. Gardner, p. 354. Philadelphia, Saunders.

Dodd, K., and Rapoport, S. (1949). American fournal of Diseases of Children, 78, 537 .

Friedman, M., Hatcher, G., and Watson, L. (1967). Lancet, 1, 703.

Gellis, S. S. (1970). The Year Book of Pediatrics, ed. S. S. Gellis, p. 41. Chicago, Year Book Medical Publishers.

Gittleman, I. F., Pinkus, J. B., and Schmerlzler, E. (1964). American Fournal of Diseases of Children, 107, 119.

Fournal of Diseases of Children, 107, 119.
Glenn, J. H. (1965). Fournal of Clinical Pathology, 1, 131.

Harvey, D. R., Cooper, L. V., and Stevens, J. F. (1970). Archives of Disease in Childhood, 45, 506 .

Johnston, C. I. (1969). British fournal of Hospital Medicine, 2, 1361.

Jones, K. H., and Fourman, P. (1966). Clinical Science, 30, 139.

Keen, J. H. (1969). Archives of Disease in Childhood, 44, 356.

Kehrer, F. (1913). Archiv für Gynäkologie, 99, 372.

Kobayashi, A., and Shiraki, K. (1967). Archives of Disease in Childhood, 42, 615.

Mader, I. J., and Iseri, L. T. (1955). American fournal of Medicine, 19, 976.

Shannon, W. B. (1929). Archives of Pediatrics, 46, 549.

Taitz, L. S., Zarate-Salvador, C., and Schwartz, E. (1966). Pediatrics, 38, 412 .

\title{
Post-Halothane Jaundice in Relation to Previous Administration of Halothane
}

\author{
WILLIAM W. MUSHIN, M. ROSEN, E. V. JONES
}

British Medical fournal, 1971, 1, 333-333

\begin{abstract}
Summary
The time interval since previous anaesthesia was compared in a surgical population in South Wales and in patients who developed jaundice after halothane. There was a significant difference in the pattern of time interval since previous general anaesthetics in the surgical population and in those patients who developed jaundice
\end{abstract}

Department of Anaesthetics, University Hospital of Wales, Cardiff WILLIAM W. MUSHIN, F.R.C.S., F.F.A. R.C.S., Professor M. ROSEN, M.B., F.F.A. R.C.S., Consultant E. V. JONES, Research Assistant after halothane. In the group who developed jaundice there was an "excess" of patients who had had a previous halothane anaesthetic within four weeks. Halothane should if possible be avoided in patients who have had it before, particularly if this was within the previous four weeks. In the case of repeat halothane anaesthetics within four weeks, the risk seems to lie between 1 in 6,000 and 1 in 22,000 .

\section{Introduction}

The rare occurrence of jaundice after halothane anaesthesia is of much concern to anaesthetists. This complication could be avoided if the use of halothane were stopped altogether. 
This would probably be unacceptable to most anaesthetists because of the considerable clinical advantages of halothane. Alternatively, some way of being forewarned would reduce the chance of this complication.

Of the several characteristics of post-halothane jaundice, one of the most consistent has been that of having had one or more previous general anaesthetics containing halothane. This has led to the current hypothesis that a sensitivity of the liver to halothane is induced by previous exposure to it. It has been advised that halothane should be avoided in any patient who has had it before. The practical value of this advice depends on whether the interval between the first and second exposures is definable.

In this paper we examine the pattern of incidence of previous general anaesthetics in a surgical population during the period in which halothane has been available and compare it with that in the cases of post-halothane jaundice reported to the Committee on Safety of Drugs (C.S.D.) or recorded in the literature.

\section{Pattern of Previous General Anaesthetics}

In three large district general hospitals in South Wales questions about previous operations were put to 558 unselected surgical inpatients after their operation. There were no important differences in the answers received between the three hospitals. Seventy-nine per cent. of the patients remembered having a previous general anaesthetic at some time in their lives. Within the 10 years since halothane became established in clinical practice $56^{\circ} \%$ of them had undergone a previous operation. The distribution of these previous operations according to the interval of time which had elapsed is shown in Fig. 1. We do not include details of the nature of the previous operations nor, by inference, the duration of general anaesthesia because this study was based on the hypothesis of sensitization as distinct from dose-dependent hepatotoxicity.

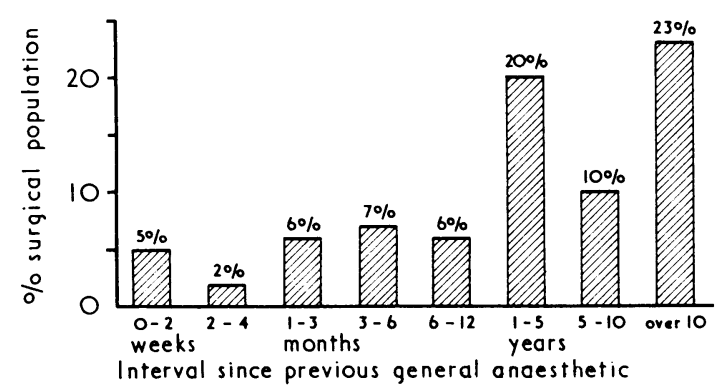

FIG. 1-Distribution by time interval of previous general anaesthetics in surgical population in general hospitals (558 patients). $79^{\circ} \%$ (441 patients) had had a previous general anaesthetic.

In the hospitals in this locality halothane was introduced into clinical practice about 1957 and rapidly became very popular. By 1960 it already formed a part of general anaesthesia in $50 \%$ of cases, by 1962 this had risen to $70 \%$, by 1965 to over $80^{\circ} \%$, and it now forms a part in nearly $90^{\circ} \%$ of all general anaesthetics. We have therefore assumed that Fig. 1, representing general anaesthetics, gives, near enough, the picture for halothane.

\section{Reported Cases of Jaundice Following Halothane}

The Committee on Safety of Drugs (C.S.D.) supplied details of 67 patients ( 39 deaths) with jaundice after halothane reported to it between 1964 and 1970 (Fig. 2). There are also reports of 74 patients ( 33 deaths) with jaundice after a second halothane administration in the English language literature which are sufficiently detailed to give reliable information about when they had had the previous general anaesthetic (Fig. 3).

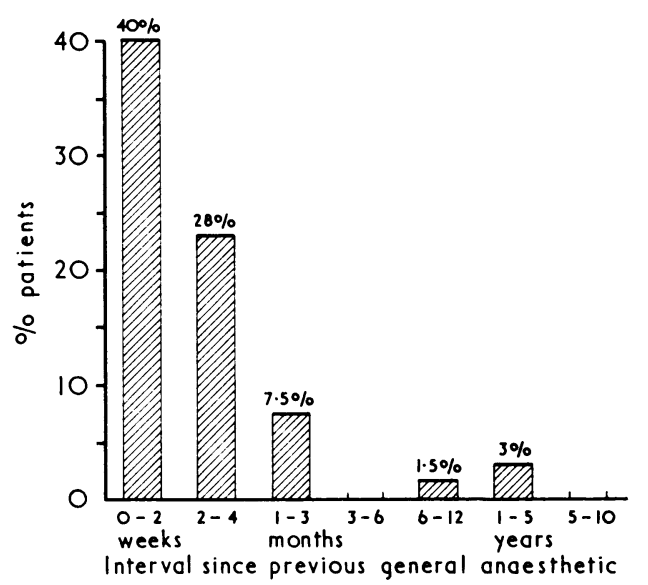

FIG. 2-Distribution by time interval of previous general anaesthetics in patients who developed jaundice after halothane (67 patients reported to C.S.D.). $80 \%$ (54 patients) had had a previous general anaesthetic recorded.

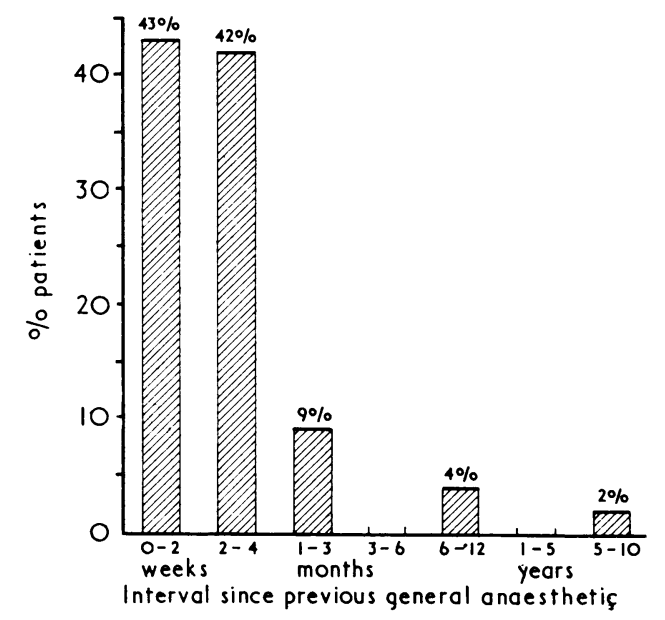

FIG. 3-Distribution by time interval of previous general anaesthetics in patients who developed jaundice after halothane ( 74 patients from literature). All patients had had a previous general anaesthetic recorded.

A statistical comparison was made of the distribution by time interval of the 441 patients in our general surgical population (Fig. 1), the 54 patients reported to the C.S.D. (Fig. 2), and the 74 patients recorded in the literature (Fig. 3), all of whom had had a previous general anaesthetic. The data show an "excess" of patients who had had repeat operations within short intervals of up to four weeks in the jaundiced patients in Figs. 2 and 3 relative to those in Fig. 1, and a "deficiency" for longer intervals. In other words the cases in the C.S.D. and in the literature (Figs. 2 and 3 ) have a very much higher proportion of short interval repeat halothane anaesthetics than does the general population (Fig. 1). The same can be said about the 72 patients who died among the cases from the C.S.D. and literature (Figs. 4 and 5). However, the question might be asked whether the excess of patients who had had a previous anaesthetic within four weeks in Figs. 2 and 3 was really related to the high death rate rather than to the short interval between the two halothane anaesthetics.

\section{Deaths and Repeat Anaesthetics}

Since those who died formed a high proportion (about $50 \%$ ) of all the patients reported to the C.S.D. or in the literature, 


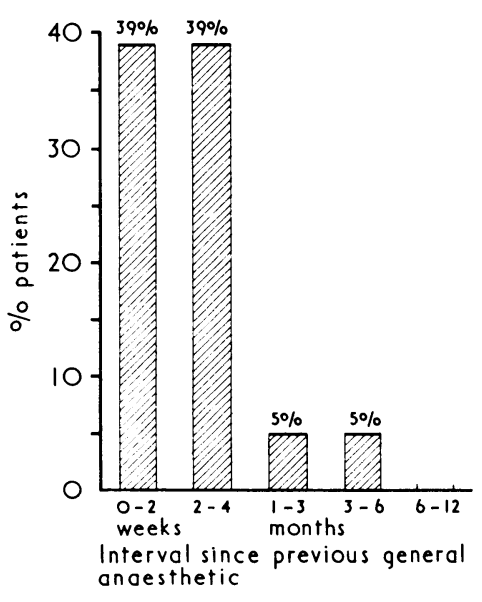

FIG. 4-Distribution by time interval of previous general anaesthetics in patients who developed jaundice after halothane and died (39 patients of 67 reported to C.S.D.).

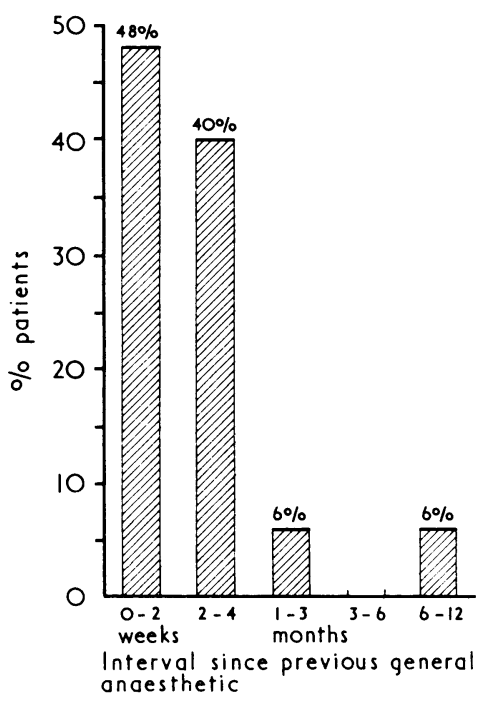

FIG. 5-Distribution by time interval of previous general anaesthetics in patients who developed jaundice after haloanaesthetics in patients who developed jaundice after halo-
thane and died ( 33 patients of 74 reported in the literature).

we examined the pattern of previous general anaesthetics in a consecutive series of patients who died after surgery in our own hospitals. In 193 consecutive surgical deaths $56 \%$ of the patients had had a previous operation, $25 \%$ of them within four weeks (Fig. 6). This is about three times higher than the proportion of the general surgical population who had had an operation within four weeks $(7 \%)$. The proportion of operations within four weeks in the 193 patients who died $(25 \%)$ was nevertheless significantly different $(P<0.001)$ from that of the 72 patients in the C.S.D. and literature series who died and who had had a previous halothane anaesthetic within four weeks $(82 \%)$.

\section{Hepatic Failure after Surgery in Cardiff Hospitals}

We examined the postmortem records of the United Cardiff Hospitals for the incidence of hepatic necrosis after surgical operations. The possibility of a case of post-surgical jaundice ending in death not coming to necropsy in our own hospitals is negligible.

During the years $1957-67$ there were 209,955 admissions to the United Cardiff Hospitals, of whom 123,516 had a general anaesthetic. Halothane was used in about $70 \%$, and, on the basis of the above study, about $7 \%(6,000)$ would have had halothane twice within a month-that is, about $70 \%$ of $123,516=86,000$, approximately $7 \%$ of this figure $=6,000$ ).

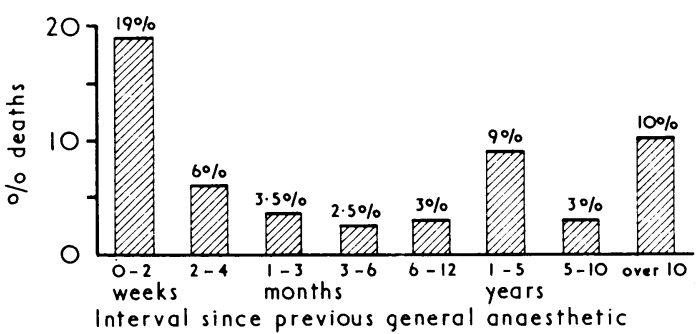

FIG. 6-Distribution by time interval of previous general anaesthetics in patients who died after a surgical operation (193 general surgical patients).

A study of the postmortem records for the whole hospital for that period showed that 15,088 patients had a necropsy. Out of this very large total we found 18 cases of acute hepatic necrosis, only three of which were post-surgical. One case, already reported (Mushin et al., 1964), died after two nonhalothane anaesthetics, another after two halothane anaesthetics within a month (this case is among those reported to the C.S.D.), and the third after one anaesthetic, probably with halothane, in a hospital outside our area. In the last case the postmortem report attributed the acute hepatic necrosis to Clostridium welchii septicaemia, and this case is therefore excluded from our calculations. There is, therefore, an incidence of one case of hepatic necrosis in about 6,000 halothane anaesthetics repeated within a month. We previously (Mushin et al., 1964) examined in detail the incidence of unexplained jaundice after halothane in our hospitals and found no other cases, apart from the second one above. Since then we have not seen any other cases; therefore, this one case represents our total incidence during a period of more than 10 years.

\section{Extrapolation of our Survey to the Surgical Population of England and Wales}

The age distribution of the surgical patients $(10,108)$ in 1963 in the United Cardiff Hospitals (Mushin et al., 1967) is compared in Fig. 7 with that in this survey. The similarity between these two distributions is close enough to make us confident

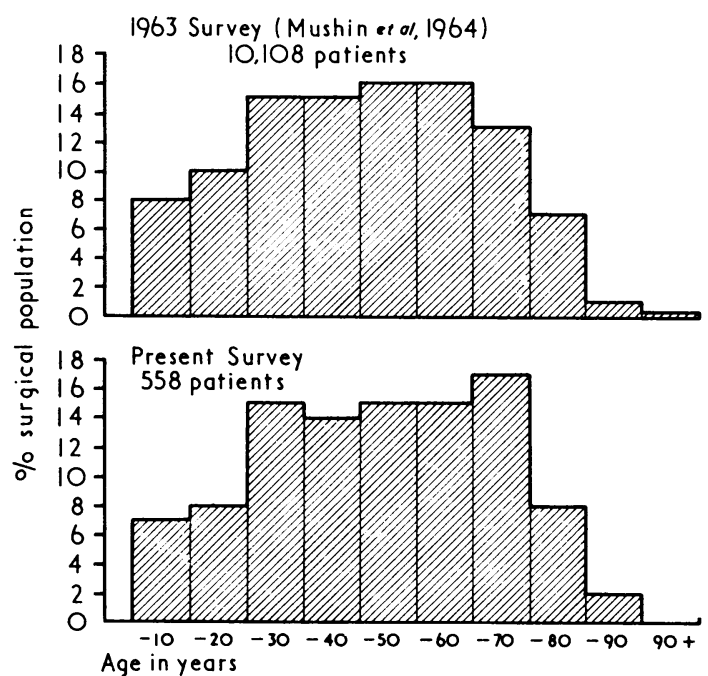

FIG. 7-Comparison of age distribution of surgical patients: 1963 and 1970 
that there has been no major change in the age distribution of the surgical population and hence probably in any other characteristics. Calculations based on our present study are therefore likely to be of the right order of magnitude for the remainder of England and Wales. Table I shows the inpatient discharges and deaths in England and Wales (Ministry of Health, 195868) and in the United Cardiff Hospitals and compares the ratio between them for the years 1957-67. This ratio has remained fairly constant, rising only a little since 1964, when the growth in surgical work in Cardiff exceeded the average for England and Wales. Furthermore, the $7 \% \%$ incidence of double halothane anaesthetics within a month in this survey is close to the figure in the National Halothane Study (1969) in the United States, which reported an incidence of $9^{\circ} \%$ in 850,000 cases. These facts support our view that our surgical sample is fairly representative of the general surgical population in the U.K. and in the U.S.A.

\section{Estimated Incidence of Hepatic Failure after Halothane}

If the usage of halothane in our hospitals is extrapolated the number of patients in England and Wales having had halothane anaesthetics in the years 1964-7 would be as shown in Table II. It also shows the number of patients in each year estimated to have had two halothane anaesthetics within four weeks, the number of reports made each year to the C.S.D., and, finally, the number of reports that would have been expected to have been made if our own incidence of one case of jaundice in 6,000 repeat-halothane anaesthetics within four weeks is applied to the whole country. It can be seen that the number of reports year by year to the C.S.D. during this period is about a third of the number expected from our figures. This discrepancy could arise either because most likely our estimate is too high or because the cases are not being reported to the C.S.D. but to some other body or are not being reported at all.

The number of patients certified to the Registrar General each year as dying from infective hepatitis fell steadily during the period 1957-67 (Table III) (General Register Office, 1958-68). Considering the rapid increase in the use of halothane in this period some effect might have been expected if fatal cases of jaundice after halothane were being certified in these categories.

\section{Cases Reported to Committee on Safety of Drugs}

The number of reports a year and the number of deaths a year is shown in Table IV. The peak in 1968 includes nine cases (two deaths) reported from one hospital. Even apart from that year, it is possible that there is a trend in an upward direction of both reports and deaths. This is partly to be expected if the proportion of patients given halothane in the country as a whole is rising. The actual number of reports and deaths is, however, very small indeed and does not parallel the increased use of halothane.

TABLE IV-Number of Reports a Year to the C.S.D. and the Number of Deaths a Year.

\begin{tabular}{l|c|c|c|c|c|c} 
& 1964 & 1965 & 1966 & 1967 & 1968 & 1969 \\
\hline $\begin{array}{l}\text { No. of reports a year } \ldots \\
\begin{array}{l}\text { No. and percentage of patients } \\
\text { who died .. }\end{array}\end{array}$ & $\begin{array}{c}7 \\
(43 \%)\end{array}$ & $\begin{array}{c}8 \\
5\end{array}$ & $\begin{array}{c}11 \\
8\end{array}$ & $\begin{array}{c}7 \\
6\end{array}$ & $\begin{array}{c}21^{*} \\
10\end{array}$ & $\begin{array}{c}13 \\
7\end{array}$ \\
\end{tabular}

*Includes 9 cases from one hospital.

TABLE v-Distribution of Patients by Age and Interval between Anaesthetics in South Wales

\begin{tabular}{|c|c|c|c|}
\hline \multirow[b]{2}{*}{$\begin{array}{l}\text { Interval between } \\
\text { Anaesthetics }\end{array}$} & \multicolumn{3}{|c|}{ Age Group } \\
\hline & $\begin{array}{c}<30 \text { Years } \\
\text { (164 Patients) }\end{array}$ & $\begin{array}{c}\text { 30-59 Years } \\
\text { (244 Patients) }\end{array}$ & $\underset{(150 \text { Patients })}{>60 \text { Years }}$ \\
\hline 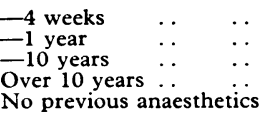 & $\begin{array}{l}8(5 \%) \\
31(19 \%) \\
51(31 \%) \\
30(18 \%) \\
44(27 \%)\end{array}$ & $\begin{array}{l}14(6 \%) \\
44(18 \%) \\
98(40 \%) \\
57(23 \%) \\
31(13 \%)\end{array}$ & $\begin{array}{l}17(11 \%) \\
26(17 \%) \\
33(22 \%) \\
39(26 \%) \\
35(24 \%)\end{array}$ \\
\hline
\end{tabular}

TABLE 1-Surgical Inpatients Discharges and Deaths

\begin{tabular}{|c|c|c|c|c|c|c|c|c|c|c|c|}
\hline & 1957 & 1958 & 1959 & 1960 & 1961 & 1962 & 1963 & 1964 & 1965 & 1966 & 1967 \\
\hline 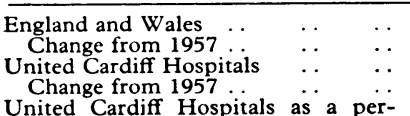 & 9,300 & $\begin{array}{c}1 \cdot 89 \mathrm{~m} \\
+30^{\circ} \\
9,300 \\
0\end{array}$ & $\begin{array}{r}1.94 \mathrm{~m} \\
+6 \% \\
9,800 \\
+5 \%\end{array}$ & $\begin{array}{r}2.00 \mathrm{~m} \\
+9 \% \\
10,200 \\
+10 \%\end{array}$ & $\begin{array}{l}2 \cdot 25 \mathrm{~m} \\
+23 \% \\
10,400 \\
+12 \%\end{array}$ & $\begin{array}{l}2 \cdot 11 \mathrm{~m} \\
+15 \% \\
10,900 \\
+17 \%\end{array}$ & $\begin{array}{l}2 \cdot 18 \mathrm{~m} \\
+19 \% \\
11,000 \\
+18 \%\end{array}$ & $\begin{array}{l}2 \cdot 27 \mathrm{~m} \\
+24 \% \\
12,400 \\
+33 \%\end{array}$ & $\begin{array}{l}2 \cdot 31 \mathrm{~m} \\
+26 \% \\
12,300 \\
+32 \%\end{array}$ & $\begin{array}{l}2 \cdot 33 \mathrm{~m} \\
+27 \% \\
13,600 \\
+46 \%\end{array}$ & $\begin{array}{l}2 \cdot 39 \mathrm{~m} \\
+31 \% \\
13,800 \\
+48 \%\end{array}$ \\
\hline $\begin{array}{l}\text { United Cardin Hospitals as a per- } \\
\text { centage of England and Wales tigures }\end{array}$ & 0.51 & 0.49 & 0.51 & 0.51 & 0.46 & $9 \cdot 52$ & 0.51 & 0.55 & 0.53 & 0.58 & 0.58 \\
\hline
\end{tabular}

TABLE II-Number of Patients having had Halothane (1964-7)

\begin{tabular}{|c|c|c|c|c|c|}
\hline & & 1964 & 1965 & 1966 & 1967 \\
\hline 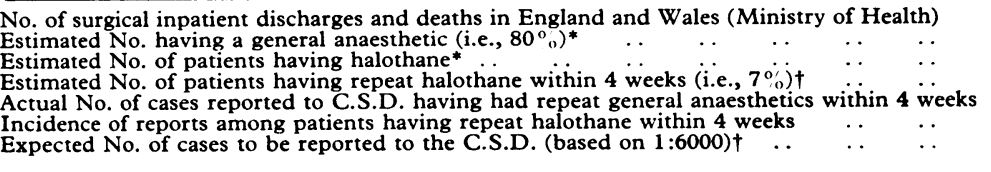 & $\begin{array}{ll}\cdots & \cdots \\
\cdots & \cdots \\
\cdots & \cdots \\
\cdots & \cdots \\
\cdots & \cdots \\
\cdots & \cdots\end{array}$ & $\begin{array}{c}2 \cdot 27 \mathrm{~m} \\
1 \cdot 82 \mathrm{~m} \\
1 \cdot 51 \mathrm{~m}(83 \%) \\
106,000 \\
5 \\
1: 21,000 \\
18\end{array}$ & $\begin{array}{c}2 \cdot 31 \mathrm{~m} \\
1 \cdot 85 \mathrm{~m} \\
1.55 \mathrm{~m}(84 \%) \\
109,000 \\
6 \\
1: 18,000 \\
18\end{array}$ & $\begin{array}{l}2 \cdot 33 \mathrm{~m} \\
1 \cdot 86 \mathrm{~m} \\
1 \cdot 58 \mathrm{~m}(85 \%) \\
111,000 \\
110 \\
1: 11,000 \\
19\end{array}$ & $\begin{array}{c}2 \cdot 39 \mathrm{~m} \\
1.91 \mathrm{~m} \\
1 \cdot 62 \mathrm{~m}(85 \%) \\
115,000 \\
3 \\
1: 38,000 \\
19\end{array}$ \\
\hline
\end{tabular}

* Based on the United Cardiff Hospital data. †Based on present survey.

TABLE III-Deaths from Infective Hepatitis and Acute Yellow Atrophy of the Liver (General Register Office (1958-68))

\begin{tabular}{|c|c|c|c|c|c|c|c|c|c|c|c|c|c|}
\hline & & & 1957 & 1958 & 1959 & 1960 & 1961 & 1962 & 1963 & 1964 & 1965 & 1966 & 1967 \\
\hline $\begin{array}{l}\text { Infective hepatitis } \\
\text { Change from 1957 } \\
\text { Acute yellow atrophy } \\
\text { Change from 1957 .. }\end{array}$ & $\begin{array}{l}\because \\
\because \\
\therefore\end{array}$ & $\begin{array}{l}\cdots \\
\cdots \\
\cdots\end{array}$ & $\begin{array}{l}292 \\
111\end{array}$ & $\begin{array}{l}245 \\
-16 \% \\
93 \% \\
-16 \%\end{array}$ & $\begin{array}{l}264 \\
-10 \% \\
102 \% \\
-8 \%\end{array}$ & $\begin{array}{l}308 \\
+5 \% \\
92 \% \\
-17 \%\end{array}$ & $\begin{array}{c}296 \\
+1 \% \\
113 \\
+2 \%\end{array}$ & $\begin{array}{r}281 \\
-4 \% \\
107 \\
-4 \%\end{array}$ & $\begin{array}{c}230 \\
-21 \% \\
106 \\
-5 \%\end{array}$ & $\begin{array}{c}196 \\
-33 \% \\
113 \\
+2 \%\end{array}$ & $\begin{array}{c}232 \\
-21 \% \\
109 \% \\
-2 \%\end{array}$ & $\begin{array}{c}207 \\
-29 \% \\
102 \\
-8 \%\end{array}$ & $\begin{array}{c}211 \\
-28 \% \\
103 \\
-7 \%\end{array}$ \\
\hline
\end{tabular}




\section{Age and Risk of Post-Halothane Jaundice}

The crude distribution by age of our surgical patients is the same as those reported to the C.S.D.-for example, for those aged $60+$ years, S. Wales $=43.6 \%$ and C.S.D. $=43.5 \%$. Age does not seem to increase the risk. However, our survey shows (Table V) that the older age group is more likely than the others to have had two anaesthetics within four weeks.

\section{Conclusions}

There is a significant association between the occurrence of post-halothane jaundice and a previous administration of halothane when the interval between the two halothane anaesthetics is four weeks or less.

The risk is in any case small and seems to lie between 1 case in 6,000 (Cardiff data) and 1 case in 22,000 (average of C.S.D. data) repeat halothane anaesthetics within four weeks. In the case of patients who had not had halothane within the previous four weeks the risk is smaller still. From the C.S.D. data it appears to be less than 1 in 600,000 . On the assumption that the average consultant anaesthetist administers 1,000 anaesthetics per annum and that if all the patients having second anaesthetics within four weeks were given halothane, in a working life of 30 years he will have administered such repeat halothane anaesthetics to about 2,000 patients. Most therefore of the consultant anaesthetists in the British Isles are likely to complete their professional lives without seeing a single case of halothane jaundice.
There seems therefore little reason, on present evidence, to stop halothane anaesthesia. Nevertheless, and in spite of the rarity of jaundice, it is reasonable to avoid halothane when it has been administered to the same patient during the previous four weeks. However, this advice assumes that there is an equally effective and safe alternative with which the anaesthetist is familiar. Otherwise it might mean that by avoiding a rare cause of morbidity or mortality a more common one is introduced.

We wish to acknowledge the help and co-operation we received from the Committee on Safety of Drugs, who not only supplied data but also gathered additional information where necessary. We also thank Professor D. Finney, F.R.S., for advice, the University Hospital of Wales (H.M.C.) and the Glantawe H.M.C. for kindly granting us permission for the surveys, and our medical and nursing colleagues for their good will. Finally, we thank the Imperial Chemical Industries Ltd. (Pharmaceutical Division) for a grant to aid this research.

\section{References}

General Register Office (1958-68). Registrar General's Statistical Review of England and Wales, for the years 1957 to 1967, Part 1, Tables Medical.

Ministry of Health (1958-68). Annual Reports, for the years 1957 to 1967, London, H.M.S.O.

Mushin, W. W., Rosen, M., Bowen, D. J., and Campbell, H. (1964). British Medical fournal, 2, 329.

Mushin, W. W., Campbell, H., and Ng, W. S. (1967). British fournal of Anaesthesia, 39, 323.

National Halothane Study (1969). Report to the Committee on Anaesthesia, Division of Medical Sciences, National Academy of Sciences, Washington, D.C.

\title{
Measurement of Blood Losses before and after Renal Transplantation
}

\author{
KEITH BODDY, A. L. LINTON, D. H. LAWSON, GEORGE WILL
}

British Medical fournal, 1971, 3, 22-24

\section{Introduction}

The use of whole-body radioactivity monitors has facilitated the measurement of blood losses (Price et al., 1962, 1964; Holt et al., 1967; Will et al., 1970a). Using this technique, we have studied blood losses in a group of patients with severe chronic renal failure.

The management of the disease was considered in three stages; the predialysis period, the period of regular dialysis therapy, and the stage following nephrectomy and successful renal homograft. It was possible to study blood losses in the

Scottish (Universities) Research Reactor Centre, East Kilbride, Glasgow

KEITH BODDY, PH.D., F.INST.P., Senior Lecturer (Health Physics and Nuclear Medicine)

Western Infirmary, Glasgow

A. L. LINTON, F.R.C.P.ED., F.R.C.P.GLAS., Consultant in Renal Diseases (Present address: Renal Unit, Victoria Hospital, London, Ontario, Canada)

D. H. LAWSON, M.B., M.R.C.P.ED., Senior Registrar, Renal Unit (Present address: Department of Clinical Pharmacology, Tufts University, School of Medicine, Waltham, Mass)

Gateside Hospital, Greenock

G. WILL, F.R.C.P.GLASG., M.R.C.P.ED., Consultant Physician same patient during different stages in the management of the disease.

\section{Patients and Methods}

The MERLIN mobile whole-body radioactivity monitor (Boddy, 1967) of the Scottish Universities Research Reactor Cer tre was used. The monitor has a shadow shield of 7 tons $(7,112 \mathrm{~kg})$ of lead with a sodium detector, $29 \cdot 2 \mathrm{~cm}$ diameter by $10.2 \mathrm{~cm}$ depth, in a central turret. Lying on a motorized couch, the subject passes beneath the detector in the supine and then in the prone position. Output pulses from the detector are taken to a T.M.C. 400-channel pulse-height analyser.

The study was carried out on six men. Each had been given from 05 to $1 \mu \mathrm{Ci}$ of ${ }^{59} \mathrm{Fe}$ intravenously some weeks earlier and red cell incorporation of ${ }^{59} \mathrm{Fe}$ was measured at 14 days after administration. Daily body ${ }^{59} \mathrm{Fe}$ loss was measured in all patients by the techniques we have previously described (Will and Boddy, 1967). All patients were suffering from severe chronic renal failure secondary to chronic glomerulonephritis, chronic pyelonephritis, or polycystic disease of the kidneys. All had creatinine clearances of $4 \mathrm{ml}$ per minute or less. At some stage all had received regular dialysis therapy with a Kolff twin-coil artificial kidney. During the course of the study both Chron-a-coils and Ultra-flo-100 coils (BaxterTravenol) were used. Dialysis was performed either twice or thrice weekly as noted. Each dialysis was of 10 hours' duration. 